\title{
Reclamation of Waterlogged Lowland in Indo-Gangetic Alluvial Plains Using Some Biodrainage Species
}

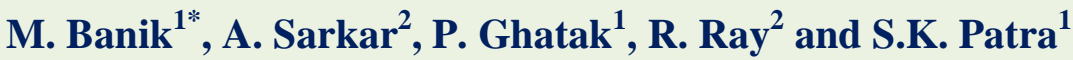 \\ ${ }^{1}$ Department of Agricultural Chemistry and Soil Science, Bidhan Chandra Krishi \\ Viswavidyalaya, Mohanpur- 741 252, West Bengal, India \\ ${ }^{2}$ Department of Soil and Water Conservation, Bidhan Chandra Krishi Viswavidyalaya, \\ Mohanpur- 741 252, West Bengal, India \\ *Corresponding author
}

\section{A B S T R A C T}

\section{Keywords}

Biodrainage,

Waterlogging, Water

table, Soil moisture,

Land reclamation,

Trees

Article Info

Accepted:

10 January 2018

Available Online:

10 February 2018
The performances of five biodrainage species were monitored for its soil moisture depletion, groundwater table depression and soil fertility improvement in waterlogged lowland of Indo-Gangetic alluvial plains of West Bengal. The results of the study showed that all biodrainage plantations had differential potential in extracting surplus water from deeper soil layers and consequent recession of groundwater table. Their efficiency followed in the sequence of Eucalyptus spp. > Bambusa arundinacea > Casuarina equisettifolia $>$ Dalbergia sissoo $>$ Musa spp. There was considerable improvement in soil properties such as $\mathrm{pH}, \mathrm{EC}$ and $\mathrm{CEC}$ beneath plantation strips compared to field without plantation, except in eucalyptus. The variable build-up of organic $\mathrm{C}$, available $\mathrm{N}, \mathrm{P}$ and $\mathrm{K}$ in surface soil was observed under the vegetation canopy compared to non-canopy site. However, fast growing eucalyptus tree was emerged as the most potential biodrainage species to remediate the waterlogging hazards and maintained the desired soil moisture balance.

\section{Introduction}

The menace of waterlogging in agricultural land can be natural and anthropogenic. Heavy rainfall and runoff accumulation, clayey soil, impeded or inadequate natural drainage, faulty irrigation water management, unlined irrigation systems, shallow water table, seepage from the upstream reservoirs and flat to concave land topography are major factors contributing to the sustained waterlogging hazards (Pandey et al., 2015). Introduction of large scale canal irrigation system has also caused a rise in groundwater table followed by waterlogging and secondary soil salinization (Ritzema et al., 2008) which adversely affecting the sustainable crop productivity (Mohamedin et al., 2010; Sarangi and Bundela, 2011). The problems of waterlogging and soil salinity are common world over. Presently, about one-third of the world's irrigated area faces the threat of waterlogging. About 60 Mha of agricultural land is already waterlogged and 20 Mha is salt affected (Heuperman et al., 2002). In India nearly 147.75 Mha is degraded area, wherein 
6.41 Mha areas confined to waterlogging problems including 1.66 Mha surface ponding and 4.75 Mha subsurface waterlogging (Anon., 2010). Waterlogging causes more harmful effects on crop production in presence of shallow saline groundwater table because salts is build up in the soil surface through the capillary action (Houk et al., 2006). It also renders deleterious effects on water and nutrient uptake by crop. The problems of waterlogging and salinity can be effectively controlled by conventional surface and subsurface drainage system which is more expensive and cause environmental degradation due to generation of enormous harmful drainage effluents. Moreover, the system requires periodic operation and maintenance cost. The limitations and shortcomings of the conventional engineering based conventional drainage techniques call for alternative approaches to keep the agriculture sustainable over the long term. Under such a situation, biodrainage is envisioned as a benign, cost effective and viable technology, which is pumping of excess soil water by deep-rooted plants using bioenergy (Kapoor, 2000; Heuperman et al., 2002; Das et al., 2005; Angrish et al., 2006). Biodrainage is the vertical drainage of soil water through high evapotranspiration by vegetation. Generally, high transpirative, salt resistant, and deep rooted plant species have been selected for land reclamation (Zohar et al., 2008). The trees once established can withdraw water from deeper layers of soil due to their deep extensive root system. This imposes removal of water vertically upward direction into the open atmosphere as evapotranspiration through vegetation (Bala $e t$ al., 2014). The technique causes a favourable water balance such that the groundwater table is maintained at a desired level below crop root zone. As a result, fields can be cultivated timely in the spaces between the tree rows to give additional monetary benefit. There is consensus that biodrainage, when properly planned and implemented, can solve the problems associated with waterlogging by lowering the water table. Biodrainage is economical because it requires only initial investment for planting the vegetation, and when established, the system could produce higher economic returns through fodder, fuel wood or fibre harvested and additionally sequesters carbon in the timber (Kumar et al., 2006; Sarvade et al., 2017). Trees can also capture nutrients below the crop rooting zone by deep root system and transfer the nutrients to surface soil for improvement of soil fertility (Ram et al., 2011). Many workers have recommended rehabilitation of such saltaffected-waterlogged lands through tree plantations having variable biodrainage quality (Dash et al., 2005; Bala et al., 2014; Roy Chowdhury et al., 2011). If trees tolerant to water stagnation are strategically introduced in the problematic areas, these can easily assist in combating waterlogging and rising water table. The whole process of biodrainage technology involves absorption, translocation and transpiration of excess groundwater into the atmosphere by deep rooted vegetation (Ram et al., 2011). However, there is paucity of information on the comparative biodrainage potential of different tree and vegetation species in different climate, soil and waterlogging conditions. Keeping all these points in view, the present study was aimed at the evaluation of biodrainage potential of some local vegetation species raised under identical field conditions on the improvement of soil moisture status, groundwater table and soil fertility in waterlogged lowland of IndoGangetic alluvial plains of West Bengal.

\section{Materials and Methods}

\section{Waterlogging scenario in West Bengal}

West Bengal experiences a widespread problem of waterlogging and soil salinity in almost every year in both irrigated and non- 
irrigated rainfed areas. Five out of seven agroclimatic zones of the state covering both the coastal and inland lowlands have been jeopardized in different extent by these twin menaces (Table 1). High rainfall and runoff situation, tidal water ingress, flat to concave topography, fine textured deep soil, impeded drainage and absence/ non-functional drainage outlets are the major causative factors for sustained waterlogging and soil salinity problems. The nature and extent of waterlogging varies due to topographical, geographical and meteorological diversities of the state. Besides the discharge of water from the upstream reservoirs outside the state boundary during the monsoon creates waterlogging at the downstream end. The spread of this malady is more pronounced in the coastal saline zone followed by the New Alluvial Zone because of lower topographical positions. In normal rainfall event about 1.33 Mha land constituting 23.9 percent of cultivable area of the state is affected by the threat of soil salinity and waterlogging. Waterlogging in cropland continues to prevail during the monsoon and some parts of post monsoon season and convert a large portion of the fertile agricultural land into both less productive and unproductive. In this land-lock area the chemical and biological process of degradation continues to operate leading to the poor agricultural productivity and resource sustainability in general and the whole socioeconomic fabric of the farming community in particular.

\section{Description of experimental site}

The experimental site is comprised of 10 hectares canal irrigated waterlogged land in village Baksha of Nadia district in West Bengal. It is located between $23^{\circ} \mathrm{N}$ latitude and $89^{\circ}$ E longitude at an altitude of $8.32 \mathrm{~m}$ above the mean sea level. The area is landlocked, which have no outlet facility to dispose of the surplus water arising from subsurface waterlogging during post monsoon and surface waterlogging during monsoon. The rainfall situation and the corresponding depth of groundwater table in different land situations throughout the year are depicted in Figure 1. The land submergence varies according to the topography and frequency and amount of rainfall. The low and medium land is severely affected by waterlogging than the high land. During the period, surface accumulation of water starts during the August and continues up to November. Beyond this period, there prevails a significant amount of subsurface waterlogging which prevents the normal land preparation for timely rabi plantation. The climate of the areas is subhumid tropic. The summer is hot and winter is moderate. May is generally the hottest month of the year. Mean maximum and minimum temperature fluctuates between $35.3-24.2^{\mathrm{O}} \mathrm{C}$ and $23.8-10.5^{\circ} \mathrm{C}$, respectively. Pre-monsoon rain is common in the month of April and May. Monsoon ceases during October and cool season sets in November. The average annual rainfall is about $1500 \mathrm{~mm}$ and normal monsoon breaks in the first week of June. Most of the showers (75-80\%) occur during the rainy months of June through September under the influence of south-west monsoon. The mean relative humidity remains high (8293\%) during June to October and reaches low (69\%) in January. The wind speed velocity around the year varies from 0.3-2.4 kmph. The pan evaporation loss ranges from 0.7-1.7 $\mathrm{mm}$ /day in the month of January which reaches 3.7-5.4 $\mathrm{mm}$ /day during May. Important physical and hydro-physical properties of the experimental soil are furnished in Table 2. The soils are in the great group of Fluvaquents. It has clay loam in texture with bulk density $1.56 \mathrm{Mg} / \mathrm{m}^{3}$, infiltration rate $1.07 \mathrm{~cm} / \mathrm{hr}, \mathrm{pH} 6.7, \mathrm{EC} 0.41$ $\mathrm{dS} / \mathrm{m}, \mathrm{CEC} 15.8 \mathrm{cmol} / \mathrm{kg}$ and organic carbon $5.94 \mathrm{~g} / \mathrm{kg}$. Available N, P and K are 182.4, 18.3 and $135.6 \mathrm{~kg} / \mathrm{ha}$, respectively. Compacted clay, silt and sand bands are 
mostly confined to the beds of rivers and canals. Illite is the dominant clay mineral and kaolinite and illite as mixed clay minerals are also found in the soils of this area.

\section{Plantation of vegetation species}

The whole waterlogged farm land was covered in different tree and vegetation species in several patches. Five isolated strips of land under coverage of eucalyptus (Eucalyptus sp.), casuarina (Casuarina equisettifolia), dalbergia (Dalbergia sissoo), banana (Musa sp.) and bamboo (Bambusa arundinacea) were categorically selected for experimentation. The adjoining open area without any vegetation species was taken as control site for comparison. The tree species planted with plant geometry of $3 \mathrm{~m}$ row to row and plant to plant distance were about five years old when observations were recorded. Banana species planted at a spacing of $2 \mathrm{~m} \times 2 \mathrm{~m}$ was one year old.

\section{Installation of observation wells}

To monitor the fluctuations of groundwater table from local ground surface during the experimental period, five shallow observation wells were installed at the centre of two rows beneath the strip plantation of each species and another one in the open non-vegetated control site. Each observation well was consisted of $5 \mathrm{~m}$ long PVC pipe with inner diameter of $6.35 \mathrm{~cm}$. The observations were recorded twice in a month with a flexible measuring tape.

\section{Soil moisture determination}

The spatial distribution of soil moisture in vertical plane beneath each vegetation species and in control plot was monitored at weekly interval commencing from first week of November 2013 to fourth week of March 2014. Soil samples were drawn from a depth of $0-15,15-30,30-45$ and $45-60 \mathrm{~cm}$ with the help of a soil auger. Fresh weight of soil samples were recorded immediately. These soil samples were oven-dried at $105^{\circ} \mathrm{C}$ for 10 hours till constant weight was obtained. The loss of moisture contents of the soil samples was determined by the gravimetric method (Jackson, 1973).

\section{Soil sampling and chemical analysis}

The depth wise composite soil samples collected were air-dried in shade and ground to pass through a 2-mm sieve for laboratory analysis. Particle size distribution of soil was carried out by international pipette method (Bouyoucos, 1962) and bulk density by core method (Black, 1965). Soil infiltration rate was determined on a pre-wetted soil (48 hours) by using double ring infiltrometer (Richards, 1954) and saturated hydraulic conductivity of soil by constant head permeameter (Klute, 1965). Soil pH and electrical conductivity (EC) were measured in 1:2.5 soil-water suspensions (Jackson, 1973). Cation exchange capacity (CEC) was determined by extracting soil with $1 \mathrm{~N}$ $\mathrm{NH}_{4} \mathrm{OAc}$ at $\mathrm{pH} 7.0$ (Schollenberger and Simon, 1945). Available $\mathrm{N}$ in the soil samples was determined by alkaline potassium permanganate method (Subbiah and Asija, 1956), organic carbon by Walkley and Black's wet-oxidation method, available P by Olsen's method and available $\mathrm{K}$ by neutral $1 \mathrm{~N}$ $\mathrm{NH}_{4} \mathrm{OAc}$ method (Jackson, 1973).

\section{Results and Discussion}

\section{Soil moisture beneath vegetation}

The results indicate that the distribution of average soil moisture contents irrespective of months under eucalyptus plantation consistently increased with increase in soil depth (Table 3), while the depletion of average soil moisture contents along the vertical plane 
compared to the control site followed the reverse trend (Table 4 ). The relative loss of soil moisture at 0-15, 15-30, 30-45 and 45-60 $\mathrm{cm}$ layer for November, December, January and February was $8.17,8.85,8.59$ and $8.15 \%$; $8.16,8.29,7.58$ and $7.32 \% ; 13.30,12.92,1.24$ and $12.26 \%$ and $14.59,11.84,11.59$ and $12.29 \%$, respectively.

It is conspicuous that maximum depletion of soil moisture beneath eucalyptus canopy was occurred in the surface layer, thereafter decreased with increasing soil depth in all the months and the rate of depletion was more pronounced in drier months (January and February) than in wetter months (November and December).

In casuarina plantation the overall soil moisture contents consistently increased down the soil profile (Table 3), whereas the overall depletion of soil moisture in comparison with control field gradually decreased downwards (Table 4).

The relative decline in soil moisture at $0-15$, 15-30, 30-45 and 45-60 cm depth was 3.73, $2.19,2.25$ and $2.58 \% ; 7.09,5.78,6.38$ and $5.18 \% ; 7.62,6.75,6.14$ and $6.02 \%$ and 9.03 , $6.20, \quad 5.49$ and $4.02 \%$ for November, December, January and February, respectively. Maximum depletion beneath plantation was observed in the topmost layer and minimum in bottommost layer in all the months and the effect was also more pronounced in drier months than in wetter months.

Under dalbergia plantation the distribution of average soil moisture contents down the soil layers was on increasing trend while the depletion of soil moisture followed the reverse trend (Tables 3 and 4). The relative reduction of soil moisture at $0-15,15-30,30-45$ and 45$60 \mathrm{~cm}$ depth was 4.15, 2.77, 2.89 and 4.68\%; $7.48,6.15,7.30$ and $5.94 \% ; 9.67,9.16,7.84$ and $8.40 \%$ and $10.27,7.81,6.79$ and $6.64 \%$ for the months of November, December, January and February, respectively. The results demonstrated that the rate of depletion of soil moisture in subsurface layers was relatively low as compared with the preceding two months.

In banana plantation the average soil moisture contents steadily increased with the increase in soil depth, however, the overall soil moisture depletion followed the reverse trend with a marginal deviation at 45-60 $\mathrm{cm}$ layer (Tables 3 and 4). The relative decline of soil moisture beneath the banana canopy at 0-15, 15-30, 3045 and $45-60 \mathrm{~cm}$ depth was $5.31,4.08,5.63$ and $5.27 \% ; 7.05,6.28,4.77$ and $4.47 \% ; 10.04$, $10.73,9.27$ and $9.33 \%$ and $12.56,8.85,8.31$ and $9.03 \%$ for November, December, January and February, respectively. It is evident that maximum soil moisture depletion was occurred in 0-15 cm layer and minimum in 45$60 \mathrm{~cm}$ layer and the rate of decline was more prominent in drier months than in wetter months.

In bamboo canopy the average soil moisture contents consistently increased in varying magnitude with increasing soil depth, however, the overall soil moisture depletion followed the reverse pattern with slight deviation at 45-60 $\mathrm{cm}$ layer (Tables 3 and 4). The relative depression of soil moisture beneath the bamboo plantation at 0-15, 15-30, $30-45$ and $45-60 \mathrm{~cm}$ depth was 7.05, 7.16, 6.68 and $7.01 \%$; 7.52, 5.74, 6.90 and $6.61 \%$; $12.04,11.71,10.89$ and $10.22 \%$ and 13.74 , $10.32,9.79$ and $11.16 \%$ for November, December, January and February, respectively.

It is clear that maximum soil moisture depletion was occurred in surface layer and minimum in bottom layer and the rate of decline was more prominent in drier months than in wetter months. 
Table.1 Agro-climatic zone wise waterlogged areas in West Bengal (million hectare)

\begin{tabular}{|l|c|c|c|c|}
\hline Agro-climatic zone & $\begin{array}{c}\text { Cultivable } \\
\text { area }\end{array}$ & $\begin{array}{c}\text { Net cropped } \\
\text { area }\end{array}$ & $\begin{array}{c}\text { Gross cropped } \\
\text { area }\end{array}$ & $\begin{array}{c}\text { Waterlogged } \\
\text { area }\end{array}$ \\
\hline Hill & 0.16 & 0.14 & 0.18 & - \\
\hline Tarai & 0.60 & 0.57 & 0.98 & 0.27 \\
\hline Old alluvium & 0.77 & 0.73 & 1.19 & 0.22 \\
\hline New alluvium & 1.72 & 1.66 & 3.52 & 0.32 \\
\hline Coastal saline & 0.86 & 0.83 & 1.35 & 0.46 \\
\hline Red and Lateritic & 1.26 & 1.15 & 1.75 & 0.06 \\
\hline Eastern plateau \& Hill region & 0.44 & 0.34 & 0.35 & - \\
\hline West Bengal & 5.81 & 5.42 & 9.31 & 1.33 \\
\hline
\end{tabular}

Source: Research Digest, AICRP on Agricultural Drainage, BCKV, 2002.

Table.2 Physical and hydro-physical properties of the experimental soil

\begin{tabular}{|c|c|c|c|c|c|c|c|}
\hline \multirow{2}{*}{$\begin{array}{l}\text { Soil depth } \\
(\mathrm{cm})\end{array}$} & \multicolumn{3}{|c|}{ Soil texture (\%) } & \multirow[t]{2}{*}{ Texture } & \multirow{2}{*}{$\begin{array}{c}\text { BD } \\
\left(\mathrm{Mg} / \mathrm{m}^{3}\right)\end{array}$} & \multirow{2}{*}{$\begin{array}{c}\mathrm{Ks} \\
(\mathrm{cm} / \mathrm{hr})\end{array}$} & \multirow{2}{*}{$\begin{array}{c}\text { Infiltration } \\
(\mathbf{c m} / \mathbf{h r})\end{array}$} \\
\hline & Sand & Silt & Clay & & & & \\
\hline $0-15$ & 20.16 & 45.66 & 34.18 & $\mathrm{cl}$ & 1.56 & 1.53 & 1.07 \\
\hline $15-30$ & 23.33 & 41.95 & 34.72 & $\mathrm{cl}$ & 1.54 & 1.48 & 0.96 \\
\hline $30-45$ & 26.91 & 35.16 & 37.93 & $\mathrm{cl}$ & 1.51 & 1.32 & 0.91 \\
\hline $45-60$ & 24.47 & 41.16 & 35.37 & cl & 1.49 & 1.24 & 0.83 \\
\hline
\end{tabular}

BD: bulk density, Ks: hydraulic conductivity, cl: clay loam

Table.3 Soil moisture content (\%) beneath different vegetation species

\begin{tabular}{|l|c|c|c|c|c|c|}
\hline Vegetation species & Soil depth (cm) & November & December & January & February & A verage \\
\hline & $0-15$ & 22.15 & 21.62 & 18.65 & 17.21 & 19.91 \\
\hline Eucalyptus & $15-30$ & 23.68 & 22.58 & 19.48 & 18.62 & 21.09 \\
& $30-45$ & 24.36 & 23.05 & 20.14 & 19.15 & 21.68 \\
\hline Casuarina & $45-60$ & 24.91 & 23.42 & 20.68 & 19.42 & 22.11 \\
& $0-15$ & 23.22 & 21.87 & 19.87 & 18.33 & 20.82 \\
& $15-30$ & 25.41 & 22.82 & 20.86 & 19.81 & 22.23 \\
\hline Dalbergia & $30-45$ & 26.05 & 23.35 & 21.54 & 20.47 & 22.85 \\
& $45-60$ & 26.42 & 23.96 & 22.15 & 21.25 & 23.45 \\
& $0-15$ & 23.12 & 21.78 & 19.43 & 18.08 & 20.60 \\
\hline Banana & $15-30$ & 25.26 & 22.73 & 20.32 & 19.47 & 21.95 \\
& $30-45$ & 25.88 & 23.12 & 21.15 & 20.19 & 22.59 \\
& $45-60$ & 25.85 & 23.77 & 21.59 & 20.67 & 22.97 \\
\hline Bambo0 & $0-15$ & 22.84 & 21.88 & 19.35 & 17.62 & 20.42 \\
& $15-30$ & 24.92 & 22.7 & 19.97 & 19.25 & 21.71 \\
\hline & $30-45$ & 25.15 & 23.75 & 20.83 & 19.86 & 22.40 \\
\hline & $45-60$ & 25.69 & 24.14 & 21.37 & 20.14 & 22.84 \\
\hline & $0-15$ & 22.42 & 21.77 & 18.92 & 17.38 & 20.12 \\
\hline & $15-30$ & 24.12 & 22.83 & 19.75 & 18.94 & 21.41 \\
\hline & $30-45$ & 24.87 & 23.22 & 20.45 & 19.54 & 22.02 \\
\hline & $45-60$ & 25.22 & 23.6 & 21.16 & 19.67 & 22.41 \\
\hline & $0-15$ & 24.12 & 23.54 & 21.51 & 24.12 & 23.32 \\
\hline
\end{tabular}


Int.J.Curr.Microbiol.App.Sci (2018) 7(2): 1028-1038

Table.4 Soil moisture depletion (\%) beneath different vegetation species

\begin{tabular}{|l|c|c|c|c|c|c|}
\hline $\begin{array}{l}\text { Vegetation } \\
\text { species }\end{array}$ & $\begin{array}{c}\text { Soil depth } \\
(\mathbf{c m})\end{array}$ & November & December & January & February & A verage \\
\hline Eucalyptus & $0-15$ & 8.17 & 8.16 & 13.30 & 14.59 & 11.06 \\
\hline & $15-30$ & 8.85 & 8.29 & 12.92 & 11.84 & 10.48 \\
\hline & $30-45$ & 8.59 & 7.58 & 12.24 & 11.59 & 10.00 \\
\hline Casuarina & $45-60$ & 8.15 & 7.32 & 12.26 & 12.29 & 10.01 \\
& $0-15$ & 3.73 & 7.09 & 7.62 & 9.03 & 6.87 \\
\hline & $15-30$ & 2.19 & 5.78 & 6.75 & 6.20 & 5.23 \\
\hline \multirow{2}{*}{ Dalbergia } & $30-45$ & 2.25 & 6.38 & 6.14 & 5.49 & 5.07 \\
\hline & $45-60$ & 2.58 & 5.18 & 6.02 & 4.02 & 4.45 \\
\hline & $0-15$ & 4.15 & 7.48 & 9.67 & 10.27 & 7.89 \\
\hline Banana & $15-30$ & 2.77 & 6.15 & 9.16 & 7.81 & 6.47 \\
\hline & $30-45$ & 2.89 & 7.30 & 7.84 & 6.79 & 6.21 \\
\hline & $45-60$ & 4.68 & 5.94 & 8.40 & 6.64 & 6.42 \\
\hline & $0-15$ & 5.31 & 7.05 & 10.04 & 12.56 & 8.74 \\
\hline \multirow{2}{*}{ Bamboo } & $15-30$ & 4.08 & 6.28 & 10.73 & 8.85 & 7.49 \\
\hline & $30-45$ & 5.63 & 4.77 & 9.24 & 8.31 & 6.99 \\
\hline & $45-60$ & 5.27 & 4.47 & 9.33 & 9.03 & 7.03 \\
\hline & $0-15$ & 7.05 & 7.52 & 12.04 & 13.75 & 10.09 \\
\hline & $15-30$ & 7.16 & 5.74 & 11.71 & 10.32 & 8.73 \\
\hline & $30-45$ & 6.68 & 6.90 & 10.89 & 9.79 & 8.57 \\
\hline
\end{tabular}

Table.5 Groundwater table fluctuation beneath different vegetation species

\begin{tabular}{|l|c|c|c|c|}
\hline \multirow{2}{*}{$\begin{array}{l}\text { Vegetation } \\
\text { species }\end{array}$} & \multicolumn{4}{|c|}{ Depth of groundwater table (m) } \\
\hline Eucalyptus & 1.92 & December & January & February \\
\hline Casuarina & 1.75 & 2.18 & 2.47 & 3.24 \\
\hline Dalbergia & 1.68 & 1.89 & 2.05 & 2.46 \\
\hline Banana & 1.63 & 1.92 & 2.14 & 2.43 \\
\hline Bamboo & 1.84 & 1.87 & 1.95 & 2.72 \\
\hline Control & 0.87 & 1.17 & 2.36 & 3.05 \\
\hline
\end{tabular}

Table.6 Important soil properties (0-15 cm layer) beneath different vegetation species

\begin{tabular}{|l|c|c|c|c|c|c|c|}
\hline $\begin{array}{l}\text { Tree } \\
\text { canopy }\end{array}$ & $\begin{array}{c}\text { pH } \\
(\mathbf{1 : 2})\end{array}$ & $\begin{array}{c}\text { EC } \\
(\mathbf{1}: 2)\end{array}$ & $\begin{array}{c}\text { CEC } \\
(\mathrm{cmo} / \mathbf{k g})\end{array}$ & $\begin{array}{c}\text { Organic C } \\
(\mathrm{g} / \mathrm{kg})\end{array}$ & $\begin{array}{c}\text { Av. N } \\
(\mathrm{kg} / \mathrm{ha})\end{array}$ & $\begin{array}{c}\text { Av. P } \\
(\mathrm{kg} / \mathrm{ha}\end{array}$ & $\begin{array}{c}\text { Av. K } \\
(\mathrm{kg} / \mathrm{ha}\end{array}$ \\
\hline Eucalyptus & 6.50 & 0.37 & 15.3 & 6.22 & 214.6 & 21.3 & 140.7 \\
\hline Casuarina & 6.74 & 0.46 & 16.4 & 6.24 & 220.1 & 22.9 & 148.4 \\
\hline Dalbergia & 7.05 & 0.60 & 19.5 & 7.19 & 241.3 & 22.2 & 167.2 \\
\hline Banana & 6.92 & 0.46 & 16.9 & 7.12 & 190.7 & 19.8 & 149.8 \\
\hline Bamboo & 7.09 & 0.46 & 17.1 & 6.32 & 197.9 & 20.7 & 155.4 \\
\hline Acacia & 6.96 & 0.48 & 17.8 & 6.67 & 221.2 & 22.4 & 166.2 \\
\hline Control & 6.70 & 0.41 & 15.8 & 5.94 & 182.4 & 18.3 & 135.6 \\
\hline
\end{tabular}

Av.: available 


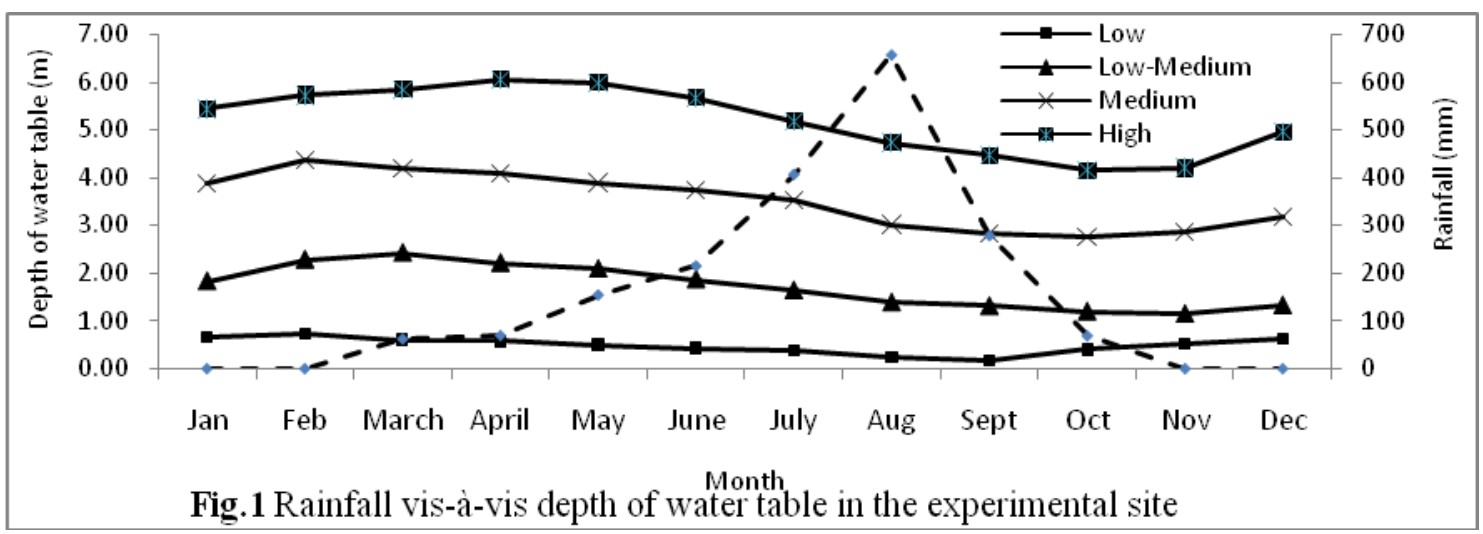

The above results showed that all the biodrainage species have differential potential in depleting soil moisture from soil profile in varying magnitude. The comparative effectiveness of different vegetation species in declining the soil moisture followed in the order of Eucalyptus spp. > Bambusa arundinacea $>$ Musa spp. > Dalbergia sissoo > Casuarina equisettifolia. Notably, the soil moisture regime under eucalyptus canopy was relatively drier than the other vegetation species under study. This indicates the high water consumption rate of eucalyptus plants in comparison to other vegetation species. This made it possible to use eucalyptus plants as a unique potential biodrainage species. This corroborates to the findings of Zahid et al., (2010) who reported that eucalyptus species used more water than other tree species. There was relatively lower soil moisture regime under eucalyptus trees in dry season than in wet season as because the roots of eucalyptus penetrate into the soil at $2.5 \mathrm{~m}$ per year and absorb water from the ground reservoir. The superiority of eucalyptus plants to capture and transpire luxuriantly the excess ground water as well as water from the upper saturated zone has been reported by Calder et al., (1997).

\section{Groundwater beneath vegetation}

The fluctuation of groundwater table in different post-monsoon months beneath biodrainage plantations vis-à-vis control site is presented in Table 7. A perusal of data shows that there was positive impact of lowering groundwater table beneath biodrainage vegetation. The rate of depression in groundwater table with different month was found maximum under eucalyptus vegetation followed by bamboo, casuarina, dalbergia and banana vegetation, respectively as compared to the control site. The comparative effectiveness in recession of water table was in the sequence of Eucalyptus spp. > Bambusa arundinacea > Casuarina equisettifolia $>$ Dalbergia sissoo $>$ Musa spp. The ability of different vegetation species in absorbing variable amounts of soil water from the deeper soil layers and consequent lowering down of groundwater table might be due to their differential growth rate pattern, canopy structure, deeper and extensive root system, larger sapwood area and evapotranspirative demand of the plants (Ram et al., 2005). However, the fast biodrainage species like eucalyptus with their large leaf area and spreading main and lateral root system was found to be much effective in recession of groundwater table and contributed significantly to counteract the adverse waterlogging problems (Angrish et al., 2006, 2009). The excellent capacity of eucalyptus tree species in controlling waterlogging and soil salinity was due to its high transpiration rate and their adaptability in varying soil-climatic conditions (Roy Chowdhury et al., 2011; Singh et al., 2014). The plantation of biodrainage species like 
eucalyptus may be a viable cost-effective alternative option to conventional engineering based drainage techniques to maintain the water table below crop root zone depth and may thus assist the farmers for restoration of waterlogged lowland for timely rabi planting.

\section{Soil properties beneath vegetation}

The physicochemical and chemical characteristics of the surface soils under different tree canopy and the adjacent soil without tree canopy are furnished in Table 6. The results show that soil $\mathrm{pH}$, electrical conductivity and cation exchange capacity were comparatively higher in fields with plantation compared with the field without plantation, except in eucalyptus plantation where these soil parameters were relatively low as compared with the control site soil. The liberation of organic acids on decomposition of leaf litterfall of eucalyptus plants might have lowered the soil $\mathrm{pH}$. The higher depression of water table by eucalyptus plantation would have ceased the migration of salts to surface layer through capillaries resulting in low EC and CEC values (Ram et al., 2011). The build-up of soil organic carbon on surface layer under the vegetation species could be accounted to the accumulation of litterfall of vegetation species on soil surface. The subsequent decomposition and incorporation of litter into the soil would have helped in raising the organic carbon status of soil. The build-up of organic carbon was higher in dalbergia plantation and lower in eucalyptus plantation in our study. Differential behaviour of the vegetation species in increasing organic carbon might be ascribed to the addition of variable amount of litterfall as well as roots and varying rates of decomposition of organic matter added through these vegetation species (Singh and Sharma, 2012). Likewise, the higher contents of available nitrogen, phosphorus and potassium on surface layer under the vegetation canopy in comparison with the non-canopy site was attributed to accumulation and decomposition of litterfall on the surface. This resulted in mineralization of organic $\mathrm{N}$ and $\mathrm{P}$ from the litter and its consequent release into the soil. Besides, the organic acids released through decomposition of litterfall reduce metal ions through chelation in soil and they compete for exchange sites, thus, releasing $\mathrm{P}$ from soil. Similarly, higher availability of soil $\mathrm{K}$ at surface layer under vegetation is attributed to liberation of $\mathrm{K}$ from decomposition of litterfall as well as solubilization of insoluble forms of $\mathrm{K}$ present in soil due to organic decomposition products (Singh and Sharma, 2012). The differences in available nutrients in soils under different vegetation species might be due to variation in total litter production, nutrient concentration of litter and varying rates of decomposition, release and subsequent accumulation in the soils. This kind of cyclic features of nutrient accumulation in soil was absent in nonvegetation control field.

All the five biodrainage species have excellent capacity for capturing and transpiration of excess water from deeper soil layers and depression of groundwater table in waterlogged lowland area. The magnitude of soil moisture depletion and concomitant groundwater table recession beneath plantation was in the order of Eucalyptus spp. $>$ Bambusa arundinacea > Casuarina equisettifolia $>$ Dalbergia sissoo $>$ Musa spp. There was improvement of soil properties like $\mathrm{pH}, \mathrm{EC}$ and $\mathrm{CEC}$ in plantation fields compared to control field, except in eucalyptus plantation. Build-up of soil organic $\mathrm{C}$, available $\mathrm{N}, \mathrm{P}$ and $\mathrm{K}$ on surface layer was found under the vegetation canopy as compared to non-canopy site. However, fast growing tree species like eucalyptus as partial substitution or in conjunction with conventional horizontal subsurface drainage 
could be planted with suitable plant geometry to remediate the sustained waterlogging and environmental problems and maintain the desired soil moisture balance for timely cultivation of rabi crops.

\section{Acknowledgement}

The fund supported by the Ministry of Water Resources, Government of India through the Indian National Committee on Irrigation and Drainage (INCID), New Delhi in carrying out this work is greatly acknowledged.

\section{References}

Angrish, R., Toky, O.P. and Datta, K.S. 2006. Biological water management: biodrainage. Current Sci., 90(7): 897.

Angrish, R., Datta, C. and Rani, V.S. 2009. Comparative bio-drainage potential of some tree species. Asian Regional Conference, New Delhi, India, 6-11 December, 2009.

Anonymous. 2010. Degraded and wastelands of India: status and spatial distribution. Indian Council of Agricultural Research, Pusa, New Delhi, pp 155.

Bala, N., Singh, G. and Bohra, N.K. 2014. Biodrainage for restoration of canal command waterlogged area in Indian desert. Indian Forester, 140(5): 462467.

Black, C.A. 1965. Methods of Soil Analysis, Part II, American Society of Agronomy, Madison, Wisconsin, USA.

Bouyoucous, G.J. 1962. Hydrometer method improved for making particle size analysis of soils. Agron. J., 54: 464-465.

Calder, I., Paul, R. and Roiser, T.W. 1997. Eucalyptus water use greater than rainfall input. Hydrol. Earth Syst. Sci., 1(2): 249-256.

Das, Ch. Jyotiprava, Sarangi, A., Singh, A.K. and Dahiya, S. 2005. Biodrainage: an alternate drainage technique to control waterlogging and salinity. J. Soil Watr. Conser. India, 4 (3\&4):149-155.

Heuperman, A.F., Kapoor, A.S. and Denecke, H.W. 2002. Biodrainage - Principles, Experiences and Applications. Knowledge Synthesis Report No. 6, International Programme for Technology and Research in Irrigation and Drainage (IPTRID), IPTRID Secretariat, FAO, Rome, pp 1-79.

Houk, E., Frasier, M. and Schuck, E. 2006. The agricultural impacts of irrigation induced waterlogging and soil salinity in the Arkansas Basin. Agric. Water Mgmt., 85(1-2): 175-183.

Jackson, M.L. 1973. Soil Chemical Analysis. Prentice Hall of India Pvt. Ltd., New Delhi.

Kapoor, A.S. 2000. Biodrainage feasibility and principles of planning and design. Proceedings of the $8^{\text {th }}$ ICID International Drainage Workshop held from $31^{\text {st }}$ Jan to $4^{\text {th }}$ Feb, 2000 at New Delhi, India, Vol. 4, pp 17-32.

Klute, A. 1965. Laboratory measurements of hydraulic conductivity of saturated soil. University of Illinois Urban Illinois.

Kumar, R., Pandey, S. and Pandey, A. 2006. Plant roots and carbon sequestration. Current Sci., 91: 885-890.

Mohamedin, A.A.M., Awaad, M.S. and Azza, R.A. 2010. The negative role of soil salinity and waterlogging on crop productivity in the northeastern region of the Nile delta, Egypt. Res. J. Agril. Biol. Sci., 6(4): 378-385.

Pandey, D.S., Singh, S.P. and Singh, G. 2015. Underprivileged agriculture: retrospection and future prospects. In: Pandey, G.B. (Eds.), Compendium of Lectures on Management of Underprivileged Agriculture. Pant University of Agriculture and Technology, Pantnagar, pp 311.

Patra, S.K. and Ray, R. 2002. Research Digest: Two decades (1982-2002) of 
research in agricultural land drainage in coastal saline land and inland low-lying land in West Bengal. BCKV-ICAR pub., pp 2-10.

Ram, J., Dagar, J.C., Khajanchi Lal, Singh, G., Toky, O.P., Tanwar, V.S., Dar, S.R. and Chauhan, M.K. 2011. Biodrainage to combat waterlogging, increase farm productivity and sequester carbon in canal command areas of northwest India. Current Sci., 100(11): 1673-1680.

Richards, L.A. 1954. Diagnosis and improvement of saline and alkali soils. Agriculture Hand Book, United States Department of Agriculture. 60.

Ritzema, H.P., Satyanarayana, T.V., Raman, S. and Boonstra, J. 2008. Subsurface drainage to combat waterlogging and salinity in irrigated lands in India: Lessons learned in farmer's fields. Agric. Water Mgmt., 95:179-189.

Roy Chowdhury. S., Kumar, A. and Brahmanand, P.S. 2011. Application of biodrainage for reclamation of waterlogged situations in deltaic Orissa. Research Bulletin No. 53. Directorate of Water Management (ICAR), Chandrasekharpur, Bhubaneswar, pp 32 .

Sarangi, A. and Bundela, D.S. 2011. Decision Support Systems in water resources management - a review. Technical Bulletin - 2011. Water Technology Centre, Indian Agricultural Research Institute. New Delhi, pp 50.

Sarvade, S., Gautam1, D.S., Kathal, D. and Tiwari, P. 2017. Waterlogged wasteland treatment through agro-forestry: a review. J. Appl. Natr. Sci., 9(1): 44-50.

Schollenberger, C.J. and Simon, R.H. 1945. Determination of exchange capacity and exchangeable bases in soil-ammonium acetate method. Soil Sci., 59: 13-24.

Singh, B. and Sharma, K.N. 2012. Depthwise distribution of soil organic carbon and nutrients under some tree species after seventeen years of plantation. J. Indian Soc. Soil Sci., 60(3): 198-203.

Singh, S.K., Verma, C.L. and Sharma, D.K. 2014. Plant height model for eucalyptus plantations for biodrainage use. Int. J. Res. Eng. Technol., 3(6): 250-259.

Zahid, D.M., Shah, F.R. and Majeed, A. 2010. Planting Eucalyptus camaldulensis in arid environment is it useful species under water deficit system. J. Bot., 42(3): 1733-1744.

Zohar, Y., Gafni, A., Morris, J. and Shalhevet, S. 2008. Eucalyptus plantations in Israel: an assessment of economic and environmental viability. New Forest, 36(2):135-157.

\section{How to cite this article:}

Banik, M., A. Sarkar, P. Ghatak, R. Ray and Patra, S.K. 2018. Reclamation of Waterlogged Lowland in Indo-Gangetic Alluvial Plains Using Some Biodrainage Species. Int.J.Curr.Microbiol.App.Sci. 7(02): 1028-1038. doi: https://doi.org/10.20546/ijcmas.2018.702.127 